\title{
Management of Pilonidal Sinus with Guggulu Aragvadha Kshara Sutra: A Case Study
}

\author{
Nidhin Mohan", Ajay Kumar Gupta² \\ ${ }^{1}$ P.G. Scholar, Third Year, P.G. Dept. of Shalya Tantra, Rishikul Campus, Uttarakhand Ayurved University, \\ Haridwar (Uttarakhand), India \\ ${ }^{2}$ Professor \& Head of the Department, P.G. Dept. of Shalya Tantra, Rishikul Campus, Uttarakhand Ayurved \\ University, Haridwar (Uttarakhand), India
}

Corresponding Author: Nidhin Mohan

\begin{abstract}
Pilonidal sinus means nest of hairs also called Jeep-bottom because it was very common in jeep drivers. It is an acquired condition commonly found in hairy males. Different surgical methods have been described for this disease such as excision and primary closure and excision with reconstructive flap, etc. However, the recurrence after surgery is very high. There is similarity between Pilonidal sinus and Shalyaja nadi vrana described in Sushruta Samhita. Acharya Sushruta has described minimally invasive Para surgical procedure viz. Kshara Sutra for Nadi vrana (Pilonidal sinus). This treatment not only minimizing the complications and recurrence but also enables the patient to resume work quickly with less discomfort. The patient attended Shalya tantra OPD of Rishikul campus, Uttarakhand Ayurved University, Haridwar and was treated with the Guggulu Aragvadha Kshara Sutra. The patient recovered well with complete excision of the tract within span of seven weeks.
\end{abstract}

Key Words- Pilonidal sinus, Nadi vrana, Guggulu Aragvadha Kshara Sutra

\section{INTRODUCTION}

Pilonidal sinus is a common condition that has controversies regarding its aetiology and treatment since its first description in the mid- $19^{\text {th }}$ century. The term is derived from a set of Latin words "pilus" meaning hair, and "nidus", meaning nest. It is popularly known as "Jeep Riders Disease”. During the world war, over 80000 soldiers in the United States army were hospitalised with this condition. ${ }^{1}$ Because a large number of soldiers who were being hospitalised for pilonidal sinus rode in jeeps, it was termed as jeep riders' disease. Pilonidal sinus is an acquired disease. Formerly, the theory of congenital origin was very popular but now a days it has greatly declined. It is epithelium lined tract, situated short distance behind the anus, containing hairs and unhealthy diseased granulation tissue. It develops due to penetration of hairs through the skin into subcutaneous tissue. It forms unhealthy granulation tissue in the deeper plane. ${ }^{2}$ The most important predisposing factor for the development of Pilonidal sinus are the existence of deep natal cleft and the presence of hair within the cleft. A deep natal cleft is a favourable atmosphere for maceration, sweating, bacterial contamination and penetration of hairs. Thus, for treatment and prevention, these causative factors must be eliminated.

Pilonidal sinus has three common representations. Nearly all patients have an episode of acute abscess formation. When this abscess resolves, either spontaneously or with medical assistance, many patients will develop chronic disease or recurrent disease after treatment. On examination typically reveals one or more small (1-2mm) dermal pits at the base of intergluteal cleft. 
Tracking from the pits (usually in cranial and lateral direction) will appear as an area of induration. With an associated abscess, the diseased area may be tender and erythematous, and draining pus may be evident. The more extensive the disease, the more prominent the findings. Commonly performed operations are complete excision with primary suture, Complete excision without skin suture, laying open of the tract with marsupialization of wound etc. Different forms of surgical techniques for pilonidal sinus have been advocated, but none of them provide good results, as the post operative recurrences are very common.

\section{Nadivrana}

Improper management or negligence of management will lead the Vrana into chronic stages, that condition is known as Nadi vrana. Improper incision and drainage of a ripened abscess and at the same time indulging in unsuitable foods by the patient, the pus retained inside ulcer and entering into the deeper tissues produces a tubular pathway of pus/channels inside them resulting in Nadi Vrana.

In Sushruta Samhita, Nidana sthana, the physician who neglects a Pakva sopha or neglects a Vrana full of pus and continues unhealthy food and activities, then the pus goes deep inside and destroying the tissues. Because of its moving inside greatly it is known as Gati and since the spread is through a tube it is called as Nadi (sinus). ${ }^{3}$

\section{Treatments in Ayurveda}

- Chhedana (Incision)

- Shalya nirharana (Removal of foreign body- hairs, pus, etc.)

- Margashodhana (Cleaning the tract)

- Ropana (Wound healing)

$\begin{aligned} & \text { Preparation of Guggulu Aragvadha } \\
& \text { Kshara Sutra }\end{aligned}$
\begin{tabular}{|l|l|}
\hline Guggulu Aragvadha Kshara sutra & Coatings \\
\hline Guggulu extract & 11 \\
\hline Guggulu extract + Aragvadha Kshara & 7 \\
\hline Guggulu extract + Haridra Choorna & 3 \\
\hline Total coatings & 21 \\
\hline
\end{tabular}

\section{Assessment Criteria}

1. Unit cutting time (UCT)

2. Pain

3. Discharge

4. Size of wound

Unit Cutting Time $=$

Total No. of days taken to cut through the track days/cm.

Initial length of the Kshara Sutra in cm.

> Time taken (in days) to cut one centimetre of the track with simultaneous healing is known as unit cutting time (UCT).

\begin{tabular}{|c|l|}
\hline $\begin{array}{l}\text { Grading of } \\
\text { Pain }\end{array}$ & \multicolumn{1}{|c|}{ Explanation } \\
\hline 0 & No complain of pain \\
\hline$+(+1)$ & $\begin{array}{l}\text { Negligible or tolerable pain. No need of any } \\
\text { medicine }\end{array}$ \\
\hline$++(+2)$ & $\begin{array}{l}\text { Localized tolerable pain, completely relieved by } \\
\text { warm fomentation }\end{array}$ \\
\hline$+++(+3)$ & $\begin{array}{l}\text { Intolerable pain, not relieved by fomentation, } \\
\text { relieved by oral analgesic. No disturbance in sleep }\end{array}$ \\
\hline$++++(+4)$ & $\begin{array}{l}\text { Continuous and intolerable pain with sleep } \\
\text { disturbance. Patient seek medical help as early as } \\
\text { possible }\end{array}$ \\
\hline
\end{tabular}

\begin{tabular}{|c|l|}
\hline $\begin{array}{l}\text { Grading of } \\
\text { Discharge }\end{array}$ & Explanation \\
\hline 0 & No sign of any discharge \\
\hline$+(+1)$ & $\begin{array}{l}\text { Occasional appearance of discharge and } \\
\text { patient uses single cotton pad in 24 hrs. }\end{array}$ \\
\hline$++(+2)$ & $\begin{array}{l}\text { Frequent appearance of discharge and patient } \\
\text { uses 3-4 cotton pads in 24 hrs. }\end{array}$ \\
\hline$+++(+3)$ & $\begin{array}{l}\text { Increased frequency of discharge and patient } \\
\text { uses 5-6 cotton pads in 24 hrs. }\end{array}$ \\
\hline$++++(+4)$ & Continuous discharge \\
\hline
\end{tabular}

\begin{tabular}{|c|l|}
\hline Grading of external Wound size & Explanation \\
\hline 0 & Healed \\
\hline$+(+1)$ & Wound within $0.5-1 \mathrm{~cm}$ \\
\hline$++(+2)$ & Wound within $1-2 \mathrm{~cm}$ \\
\hline$+++(+3)$ & Wound within $2-3 \mathrm{~cm}$ \\
\hline$++++(+4)$ & Wound more than $3 \mathrm{~cm}$ \\
\hline
\end{tabular}

\section{CASE STUDY}

A 19-year-old hirsute male patient attended the Shalya tantra OPD at Rishikul campus, Uttarakhand Ayurved University, Haridwar with registration number S6448/15360 complaints of serous discharge from mid gluteal cleft since 2 months. Occasionally, feels throbbing type of pain, itching and discomfort at natal cleft and low back region. Patient had history of an abscess at the site of opening before 2 months. For that he took antibiotics and anti-inflammatory medicines from an 
allopathic doctor for 7 days and got relief from acute condition. Gradually he developed a small opening near gluteal cleft. Patient had no history of bleeding per rectum or painful defaecation or mucus or any kind of discharge through anus. There is no history of Diabetes mellitus, Hypertension, Tuberculosis, etc. Patient had good appetite, bowel habit, sleep, not any kind of addiction. Blood pressure, pulse rate, respiratory rate was in normal limits.

\section{Local Examination}

Local examination was done in prone position of patient, the findings were: patient was hairy and had a small opening at mid gluteal cleft with good amount of hair nearby. During palpation, a cord like indurated structure was felt at the opening of sinus. Mild tenderness and watery discharge were present while palpation of local site. There was no any other opening or any lump near or in gluteal cleft. Probing was done from the opening to accessed branching and extension of the tract. About $7 \mathrm{~cm}$ tract was found during probing in mid gluteal cleft. By complete thorough examination the diagnosis was confirmed as pilonidal sinus. All routine blood investigations were ruled out. All situations about disease and its management were explained to the patient and finally was planned for Kshara Sutra therapy under local anaesthesia as day care procedure.

\section{Essential steps of Kshara Sutra application}

After taking all aseptic precautions, patient was kept in prone position to perform the application of Kshara Sutra. Kshara Sutra procedure was performed under local anaesthesia. The malleable probe was inserted gently into the tract and was assessed by means of probe. The probe was pushed inside the tract till the tip of the probe was felt by the finger and then tip of the probe was taken out through an artificial opening at the other end of Pilonidal sinus. Then Kshara Sutra was threaded in the eye of the probe. The probe was gently taken out in such a manner that the entire sinus tract was threaded by Kshara Sutra. During this procedure, tuft of hair was seen to come out of the pilonidal sinus tract along with foul sero-purulent discharge. After that, the two terminuses of the Kshara Sutra were ligated outside. Then operated area was washed with normal saline and bandaged with cotton pad. There was no complication during the procedure. Vitals of patient were within normal limits.

\section{Post-operative Management}

Patient was advised to mobilize immediately after surgery. Patient was instructed to do warm fomentation twice a day and to keep the operated area clean and dry, and the Kshara Sutra was changed weekly by rail road technique and length were measured and recorded. The thread was changed weekly because the thread act as an ideal media for drug delivery in the minute channel and further presence of thread in the tract keeps it patent for 7 days enabling the infected material to drain out, which is essentially required for healing of Pilonidal sinus. Weekly local part preparation was ensured.

\section{OBSERVATION AND RESULT}

\begin{tabular}{|l|l|l|l|l|l|l|l|l|l|l|}
\hline Symptom & $\begin{array}{l}\mathbf{1}^{\text {st }} \\
\text { day }\end{array}$ & $\begin{array}{l}\mathbf{7}^{\text {th }} \\
\text { day }\end{array}$ & $\begin{array}{l}\mathbf{1 4}^{\text {th }} \\
\text { day }\end{array}$ & $\begin{array}{l}\mathbf{2 1}^{\text {st }} \\
\text { day }\end{array}$ & $\begin{array}{l}\mathbf{2 8}^{\text {th }} \\
\text { day }\end{array}$ & $\begin{array}{l}\mathbf{3 5}^{\text {th }} \\
\text { day }\end{array}$ & $\begin{array}{l}\mathbf{4 2}^{\text {nd }} \\
\text { day }\end{array}$ & $\begin{array}{l}\mathbf{4 9}^{\text {th }} \text { day } \\
\text { day }\end{array}$ & $\begin{array}{l}\mathbf{5 6}^{\text {th }} \\
\text { day }\end{array}$ & $\begin{array}{l}\mathbf{6 3}^{\text {rd }} \\
\text { day }\end{array}$ \\
\hline dain & +2 & +2 & +1 & +1 & +1 & +1 & +1 & +1 & 0 & 0 \\
\hline Discharge & +2 & +3 & +3 & +2 & +1 & +1 & +1 & 0 & 0 & 0 \\
\hline $\begin{array}{l}\text { Length of } \\
\text { tract }\end{array}$ & $7 \mathrm{~cm}$ & $5 \mathrm{~cm}$ & $4 \mathrm{~cm}$ & $3 \mathrm{~cm}$ & $2.5 \mathrm{~cm}$ & $1.5 \mathrm{~cm}$ & $1 \mathrm{~cm}$ & $\begin{array}{l}\text { Cut } \\
\text { through }\end{array}$ & 0 \\
\hline $\begin{array}{l}\text { Size } \\
\text { wound }\end{array}$ & Nil & Nil & Nil & Nil & Nil & Nil & Nil & +1 & 0 \\
\hline
\end{tabular}

Unit Cutting Time (UCT) $=49 / 7=7$ days $/ \mathrm{cm}$ 
The patient had followed instructions strictly. From $14^{\text {th }}$ day onwards there was remarkable relief in pain, but the discharge of pus was slightly increased. In first two weeks there was profuse serous discharge and it got diminished after the progression of cutting of the tract by Guggulu Aragvadha Kshara Sutra. After $49^{\text {th }}$ day there was no discharge of pus. Initial tract length was $7 \mathrm{~cm}$ and cut through of the tract was occur on $49^{\text {th }}$ day. After 'cut through' there was a small wound and it was completely healed within $56^{\text {th }}$ day. $100 \%$ relief from all symptoms was achieved in 2 months.
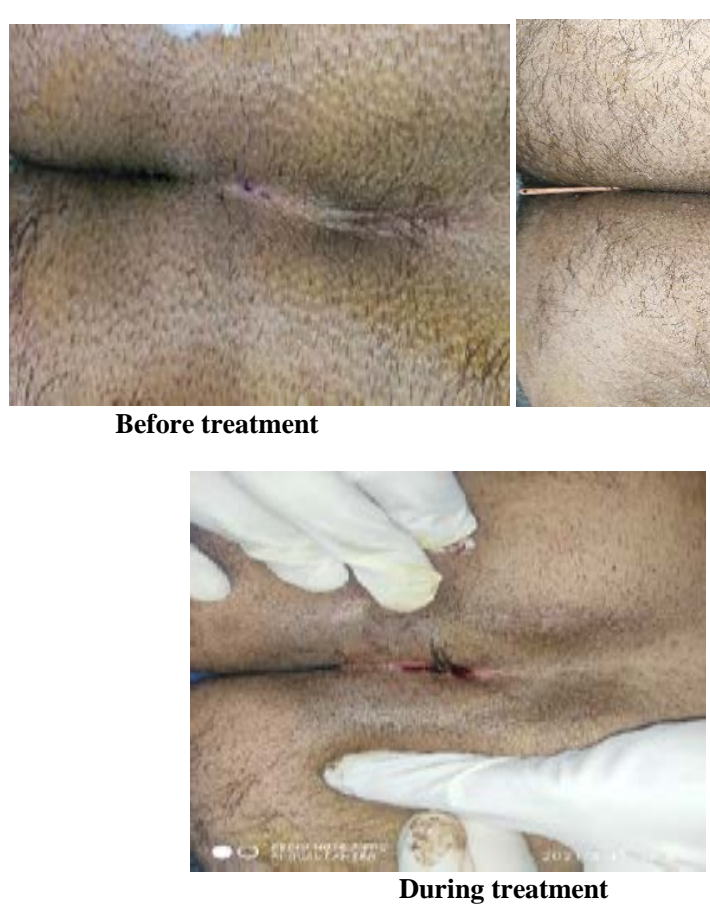

\section{DISCUSSION}

Acharya Sushruta has described Baala as one of the Shalya and it is the main reason for the Pilonidal sinus disease. In this case, Patient is obese with deep natal cleft and he is having the habit of riding the bike regularly. Because of overweight, there is a chance of friction of hairs between gluteal region. Improper cleaning of anal region after defaecation and excessive sweating of this particular area may be contributing factor for this condition. Proper drainage of pus may not be done in Pakwasvastha and intake of medicines for subsiding the condition aggravated his disease. There are so many modalities are available in the management of Pilonidal sinus. Nowadays Kshara Sutra is becoming more potential to treat Pilonidal sinus. The Kshanana and Ksharana properties of Kshara Sutra cuts pilonidal sinus tract from inside gradually and initiate simultaneous healing. This is
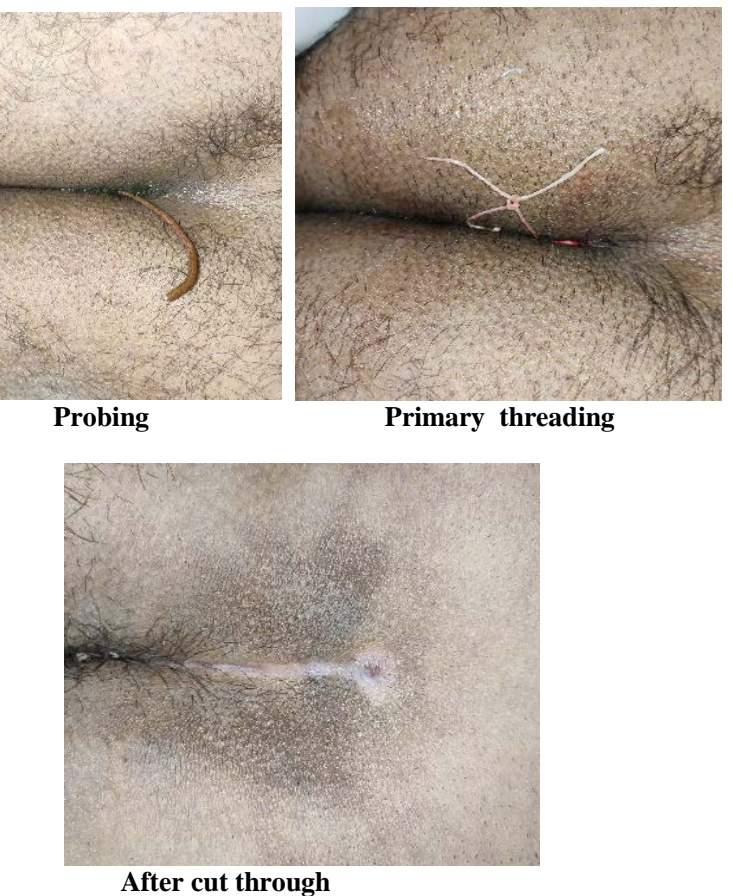

After cut through

because of the wound healing (Ropaka), Analgesic (Vedanahara), Antiinflammatory (Shothahara) properties of Aragvadha, Haridra and Guggulu. ${ }^{4}$ Guggulu Aragvadha Kshara Sutra has analgesic property, this is probably due to Vata shamaka and Shoolapaharaka karmas of Guggulu and Aragvadha and the Chemical constituents like Flavonoids and Guggulusterone. Aragvadha effectively pacifies Kapha and Pitta dosha and Chemical constituents like Flavonoids, Essential oils and $\beta$-Sitosterol of Guggulu and Curcumin of Haridra possesses Antibacterial action hence it alleviates the pus discharge, inflammation and which aids wound healing.

\section{CONCLUSION}

The modern surgical treatment of Pilonidal sinus is often unsatisfactory. In majority of cases, recurrences are common 
after surgery. Kshara Sutra is safe, cost effective and minimally invasive procedure, promotes healthy healing with negligible recurrence rate. Management of pilonidal sinus with Guggulu Aragvadha Kshara Sutra is found to be very effective, and can be successfully used as a curative measure in cases of Pilonidal sinus.

Acknowledgement: None

Conflict of Interest: None

Source of Funding: None

\section{REFERENCES}

1. S. Das: A concise text book of surgery, publisher Dr. S Das, $5^{\text {th }}$ edition reprinted 2009, chapter 54, pg no-1099

2. Bailey \& Love's short practice of surgery, $27^{\text {th }}$ edition, pg no- 1347

3. Sushruta, Sushruta Samhita-edited with Ayurveda Tatwa sandipika Hindi commentary by Kaviraja ambikadutta shastri, Choukamba Sanskrit Sansthan;2010, Vol1, Nidana Sthana 10/9-14

4. Dravyaguna Vijnana; Dr Prakash L Hegde, Choukamba publications, Newdelhi, chapter-34, page no-320

How to cite this article: Mohan N, Gupta AK. Management of pilonidal sinus with guggulu aragvadha kshara sutra: a case study. Int $J$ Health Sci Res. 2021; 11(11): 156-160. DOI: https://doi.org/10.52403/ijhsr.20211120 